\title{
Taxonomy, nomenclature, and evolution of the early schubertellid fusulinids
}

Vladimir I. Davydov

Acta Palaeontologica Polonica 56 (1), 2011: 181-194 doi: http://dx.doi.org/10.4202/app.2010.0026

The types of the species belonging to the fusulinid genera Schubertella and Eoschubertella were examined from publications and type collections. Eoschubertella in general possesses all the features of Schubertella and therefore is a junior synonym of the latter. However, the concept of Eoschubertella best describes the genus Schubertina with its type species Schubertina curculi. Schubertina is closely related to the newly established genus Grovesella the concept of which is emended in this paper. Besides Schubertella, Schubertina, and Grovesella , the genera Mesoschubertella, Biwaella are reviewed and three new species, Grovesella nevadensis, Biwaella zhikalyaki, and Biwaella poletaevi, are described. The phylogenetic relationships of all Pennsylvanian-Cisuralian schubertellids are also proposed. Barrel-shaped Grovesella suggested being the very first schubertellid that appears sometimes in the middle-late Bashkirian time. In late Bashkirian it is then developed into ovoid to fusiform Schubertina. The latter genus gave rise into Schubertella in early Moscovian. First Fusiella derived from Schubertella in late Moscovian, Biwaella-in early Gzhelian and Boultonia-in late Gzhelian time. Genus Mesoschubertella also developed from Schubertella at least in Artinskian, but may be in late Sakmarian.

Key words: Foraminifera, Fusulinida, Schubertellidae, evolution, taxonomy, Permian, Carboniferous.

Vladimir I. Davydov [vdavydov@boisestate.edu] Permian Research Institute, Department of Geosciences, Boise State University, Boise, ID, 83725, USA.

This is an open-access article distributed under the terms of the Creative Commons Attribution License (for details please see creativecommons.org), which permits unrestricted use, distribution, and reproduction in any medium, provided the original author and source are credited. 
FoF Full text $(1,906.3 \mathrm{kB})$ 